\title{
Fysisk aktivitet - aldri for sent!
}

Fysisk inaktivitet er en risikofaktor for hjerte- og karsykdom. I motsetning til mye annet er det fysiske aktivitetsnivået noe den enkelte selv kan gjøre noe med for å bevare helsen og i beste fall forlenge livet. Økt fysisk aktivitet er en erklært helsepolitisk målsetting. Helsedirektoratet anbefaler minimum 30 minutter moderat fysisk aktivitet daglig for voksne. Anbefalingen kan virke svært forsiktig, det er en påminnelse om hvor stillesittende vi er blitt.

I dette nummer av Tidsskriftet presenterer Ingar Holme \& Sigmund A. Anderssen resultater fra en oppfølging av Oslo-undersøkelsen, som ble startet for mer enn 40 år siden $(1,2)$. Over 25000 menn i alderen 40-50 år ble i perioden 1972-73 invitert til screening med hovedvekt på hjerte- og karsykdommer. Undersøkelsen var svært relevant og godt begrunnet i den høye hjerte- og kardødeligheten som hadde utviklet seg etter den annen verdenskrig. I undersøkelsen ble det slått fast at de viktigste risikofaktorene for hjertedød var tobakk, høyt kolesterolnivå og høyt blodtrykk, og at koronare risikofaktorer er mest utbredt i lavere sosioøkonomiske klasser (3).

I år 2000 ble de gjenlevende fra Oslo-undersøkelsen invitert til en oppfølging med kartlegging av fysisk aktivitet og røykevaner. Holme \& Anderssen presenterer nå data fra 12 års oppfølging etter Oslo 2-undersøkelsen, med vekt på hvilken betydning fysisk aktivitet og røykevaner har for dødeligheten.

Hovedbudskapet i artikkelen er at fysisk aktivitet er assosiert med redusert dødelighet - også for eldre menn. En økning av aktivitetsnivået selv i høy alder hadde positiv effekt, og nytten av fysisk aktivitet var på nivå med helsegevinsten av å ikke røyke. Resultatene er ikke overraskende og samsvarer godt med resultatene fra andre studier $(4,5)$. Selv om studien har svakheter, er dette viktige oppfølgingsdata fra en sentral og stor norsk hjerte- og karundersøkelse. Med stor styrke påvises assosiasjoner mellom egenrapportert fysisk aktivitet og risiko for tidlig død. Om det er kausalitet, kan ikke studien si noe om, det forblir en hypotese. Selv om det blir korrigert for en rekke faktorer, er muligheten for restkonfundering klart til stede. Var deltakerne fysisk aktive fordi de hadde god helse og gode leveutsikter, og var fysisk inaktivitet forårsaket av underliggende sykdom som påvirket leveutsiktene? I en aldrende populasjon er dette spesielt relevant, og forfatterne diskuterer det godt. Selv om det er metodologiske utfordringer, styrker studien grunnlaget for å anbefale regelmessig fysisk aktivitet også for eldre. Uttrykket «aldri for sent» er nærliggende.

I en nyere metaanalyse ble effekten av fysisk aktivitet og farmakologisk intervensjon på dødelighet sammenliknet hos pasienter med koronarsykdom, hjertesvikt, prediabetes og gjennomgått slag (6). Konklusjonen var at fysisk aktivitet og farmakologisk intervensjon hadde omtrent samme mortalitetsreduserende effekt. Ikke overraskende var antall studier på effekten av fysisk aktivitet vesentlig færre enn antall farmakologiske studier. Det finnes ingen randomisert studie som entydig kan dokumentere at fysisk aktivitet gir lavere dødelighet. Hvis nytten av trening var studert med samme iver som nytten av medikamenter, hadde vårt kunnskapsgrunnlag kanskje vært annerledes. Hvis kunnskapsbasert medisin virkelig skal fortjene sitt omdømme, må vi også gjennomføre studier på intervensjoner som ikke nødvendigvis gir utsikter til stor økonomisk gevinst. Innen hjerte- og karsykdommer har det de siste tiårene vært en rekke studier på medikamentintervensjoner, men «treningspillen» er ikke tilsvarende godt undersøkt. Betydningen av de farmakologiske studiene skal ikke underslås, de har ført til bedre behandling og økt overlevelse ved flere tilstander. De tilsvarende store og vel gjennomførte studier på effekten av trening har manglet. Det er derfor en reell fare for at det vi definerer som kunnskapsbasert behandling, består i mer medikamenter og mindre fysisk aktivitet enn det som kunne gitt de aller beste resultater. Incentivene har vært ulike, muligheten for økt salg av joggesko og vandrestaver har ikke vært en like sterk drivkraft som utsiktene til økonomisk gevinst gjennom mer medikamenter til mange.

Hva er så utfordringene? Den gunstige effekten av fysisk aktivitet vet vi mye om, men det er mangel på kunnskap om hvordan vi i primær- og sekundærprevensjonen skal få folk til å øke og opprettholde sin fysiske aktivitet.

Holme \& Anderssen konsentrerer seg i sin artikkel om risikofaktorene inaktivitet og røyking. Dette er risikofaktorer som er ulikt fordelt i befolkningen ved at de er mer til stede i lavere sosiale lag. Dermed er vi over på den kanskje største helsepolitiske utfordringen vi har i vårt land - den økende sosiale ulikheten i helse. Erkjennelsen av den økende sosiale gradienten tvinger oss til nytenkning når det gjelder valg av strategier for å nå resultater i forebyggende arbeid. Vår store utfordring nå er å sørge for at den godt etablerte kunnskapen vi har om fysisk aktivitet, kosthold og tobakk, kommer til anvendelse også hos dem som trenger det aller mest. Dette er ikke en oppgave bare for helsevesenet, det er en problemstilling som like mye hører hjemme på det politiske plan.

\section{Rune Wiseth}

rune.wiseth@stolav.no

Rune Wiseth (f. 1954) er klinikksjef ved Klinikk for hjertemedisin, St. Olavs hospital, og professor i hjertesykdommer ved Norges teknisk-naturvitenskapelige universitet.

Forfatter har fylt ut ICMJE-skjemaet og oppgir ingen interessekonflikter.

\section{Litteratur}

1. Holme I, Anderssen SA. Fysisk aktivitet, røyking og dødelighet hos menn som deltok i Oslo-undersøkelsene i 1972 og 2000. Tidsskr Nor Legeforen 2014; 134 $1743-8$.

2. Leren P. Askevold EM, Foss OP et al. The Oslo study. Cardiovascular disease in middle-aged and young Oslo men. Acta Med Scand Suppl 1975; 588: 1-38.

3. Holme I, Helgeland A, Hjermann I et al. Coronary risk factors and socioeconomic status. The Oslo study. Lancet 1976; 2: 1396-8.

4. Wisløff U, Nilsen TI, Drøyvold WB et al. A single weekly bout of exercise may reduce cardiovascular mortality: how little pain for cardiac gain? 'The HUNT reduce cardiovascular mortality: how little pain for cardiac gain?
study, Norway'. Eur J Cardiovasc Prev Rehabil 2006; 13: 798-804.

5. Wen CP. Wai JP, Tsai MK et al. Minimum amount of physical activity for reduced mortality and extended life expectancy: a prospective cohort study. Lancet 2011; 378: $1244-53$.

6. Naci H, loannidis JP. Comparative effectiveness of exercise and drug interventions on mortality outcomes: metaepidemiological study. BMJ 2013; 347: f5577. 